\title{
Exploring Adolescent Characteristics, Experiences and Socio-environmental Responses on Premarital Pregnancy in Central Java Indonesia
}

\author{
Zahroh Shaluhiyah ${ }^{1}{ }^{*}$, Antono Suryoputro ${ }^{1}$, Aulia Novelira $^{2}$, Ratih Indraswari ${ }^{1}$ \\ ${ }^{1}$ Faculty of Public Health, Diponegoro University, 50275 Semarang, Indonesia \\ ${ }^{2}$ Faculty of Medicine, Gadjah Mada University, 55281 Yogyakarta, Indonesia
}

\begin{abstract}
The aim of this study was to explore the phenomena of premarital pregnancy by exploring adolescent characteristics, experiences and socio- environmental responses. It employs descriptive study and phenomenology approach using in-depth interviews to explore adolescent's premarital pregnancy experiences. A total of 49 adolescents aged 12-19 years with premarital pregnancy were willing to participate in this study and 10 respondents were interviewed in more deeply. The data were analyzed using thematic content analysis. The average age of the respondents were 17 years old and most of them had low educational level. Their knowledge on sexual and reproductive health was categorized as lack of knowledge. Nearly half of them were more permissive so that partner influence to have sex is main factor that is difficult to resist by the respondents. Parents and community responses were initially forced to resist their premarital pregnancy, but it gradually became normally accept. Premarital pregnancy was more influenced by peer's permissive attitude, frequent access to pornography, and lack of parental supervision. There were four respondents who tried to seek abortion. It is recommended to provide comprehensive sexual and reproductive health education to adolescents in order to prevent premarital pregnancy.
\end{abstract}

\section{Introduction}

The population of Indonesia in 2018 was 267.6 million, and 26.67 percent of them were teenagers. The number of adolescent population affected the development of social, economic and demographic trends for the present or in the future [1]. The population of adolescents aged 10-24 years needs serious attention because teenagers are the future of the nation and they fall into the category of school and of working ages. Then, they are at risk of reproductive health problems, such as premarital sexual behaviour, drug, and sexually transmitted diseases including HIV/AIDS [2].

The lack of skills and knowledge about sexuality and reproductive health in adolescents make teenagers experience maturity-gap which is the difference in physical and mental

\footnotetext{
* Corresponding author: shaluhiyah.zahroh@gmail.com
} 
maturity. The maturity differences could encourage teens to do risky things. Adolescents are considered as a group at risk sexually because they have a great curiosity and want to try something new which is not supported by sufficient knowledge. The sooner sexual maturity and the longer age of marriage are the causes of the growing number of teens who have sex before marriage [3].

The prevalence of pregnancy in adolescents has an impact on less optimal growth for the mothers and their babies because the nutritional needs during the growth and development of adolescents are still urgently needed by their body. In addition, immature physical development including their reproductive organs make teens prone to risk during pregnancy, giving birth, and postpartum [4-6]. The linear growth is generally completed in 16-18 years and continues with the maturation of pelvic cavity growth in a few years after the completion of linear growth. Rudimentary linear growth and maximum bone mass are not reached until the age of 25 years $[7,8]$. The development of pelvic cavity is maximal after the height growth point stop between 18 and 22 years. Someone is mature and responsible for reproduction as housewives psychologically and biologically between the ages of 20 to 30 years [9].

The incidence of adolescents pregnancy in Indonesia increase continuously, from $1.97 \%$ of adolescents in 2013 to $16.4 \%$ in 2017 [10, 11]. Premarital pregnancy data obtained from PILAR PKBI of Central Java, there were 64 cases in 2013 which 59.4\% were teenagers from rural areas [12]. The difficulties in finding the unwanted pregnancy cases was likely due to unreported data and only recorded the ones visiting the clinics. In accordance with the culture and values of eastern society, the prevalence of unwanted pregnancy is shameful and must be covered as a disgrace to the family. There is a social sentence given to the perpetrators and victims. It causes many unreported cases for unwanted pregnancy by individuals, families and institutions such as schools, midwifery practices and health centers. Inaverage, there were $8 \%$ of abortions committed by adolescent aged less than 19 years due to unwanted pregnancy [13].

Demak Regency is one of regencies in Central Java known as the cultural district with quite high religiosity. The close correlation between the value of premarital sexual behaviour and someone's religiosity is sometimes one of the benchmarks in question when there is adolescent's immoral and deviant behaviour. In addition, in views of socio-environmental factors, Demak Regency is one area in the northern coast of Central Java which connects the major cities in Java. People in the areas have distinctive characteristics, such as more heterogeneous and open to change, compared with rural communities. It can lead to many influences coming from out of the community which could not be screened for the positive or negative ones [14].

Based on data from the City Health Office of Demak Regency in 2016, the number of adolescent targets aged 10-18 years was 92,124 people. At the age ranges, 928 pregnant adolescents were under the age of 18 years, or about $1 \%$ of them already gave birth/ delivery. Some trends suspected as the cause of early pregnancy other than early marriage were due to economic factors, family, or culture. It also occurred due to unwanted pregnancy which happened outside of marriage. By using the data of the urine tests to brides, the data of delivery of adolescents, and the data of unwanted pregnancies from all health centers in subdistricts, it was found that the number of cases of premarital pregnancy was the highest from January 2018 to March 2018 located in some Sub-Districts such as Guntur, Karangawen, Karangtengah, Bonang, and Dempet [15]. The aim of the study was to explore personal characteristics and experiences of adolescent girls with premarital pregnancy including socio-environmental responses in these sub-districts. It is expected that appropriate interventions could be developed for adolescents' sexual reproductive health to prevent premarital pregnancy in Demak Regency and other regencies in Central Java. 


\section{Research method}

It was a descriptive study and phenomenological approach to explore adolescent girl characteristics, experiences and socio-environmental responses on premarital pregnancy $[18,19]$. Samples were adolescent girls aged 10-19 years who experienced with premarital pregnancy in 5 sub-districts in Demak Regency based on the data from urine tests to the brides in a period from January to June 2018 carried out by the health centers and the data of adolescent pregnancy recorded by the midwives. There were 103 documented cases of pre-marital pregnancy, but there were only 49 of them that could be involved. The remaining of 18 respondents were on unknown addresses, 17 respondents worked out of the city or followed their husbands, 8 adolescents were not willing to participate, and 11 adolescents were not permitted by their parents.

The interviews with semi-structured questionnaires were conducted to 49 respondents, while more in-depth explorations were conducted to the 10 informants selected by the younger age that was ranged 12-15 years old and older aged (16-19 years old) and some has a history of trying to get an abortion. To reach the informants, the researchers were assisted by midwives to help initial approach or rapport. After the respondents/ informants felt comfortable, the researchers conducted their own approach for explaining the purpose of the study. The in-depth interview began by discussing general topics. After the respondents felt trust and comfortable discussing with the researchers, the researcher started to conduct the interviews on more sensitive topics.

The research variables include demographic characteristics such as age, religion, education, occupation, number of informants and parental income, type of house, and family type, and the characteristics of the couples. The personal characteristics include demographic variables, knowledge, attitudes, religiosity, and locus of control. The characteristics of socioenvironment variables include access to pornography, parental attitudes, peer attitudes, community attitudes, and experiences in dating and sexual behaviour. The data collected were analyzed descriptively, while the qualitative data was analyzed using thematic content analysis.

To provide trustworthiness, this study using triangulation by interviewing parents of informants and village midwives to explore their responses of adolescent premarital pregnancy. Peer debriefing was also conducted among the researchers to share experiences including barriers during data collection. Before the interviews conducted, the respondents were delivered informed consent that to be signed as the willingness to participate in this study, and the guarantee of data privacy / confidentiality. The ethical clearance was approved by No. 147/ EC/ FKM/ 2015 by the Commission on Health Research Ethics of FKM UNDIP.

\section{Results}

\subsection{Adolescent characteristics}

Table 1 shows the average age of the respondents was 17 years, with a little higher proportion to the aged under 17 years $(55.1 \%)$. The youngest age was 12 years and the oldest was less than 20 years old. Most of them had low educational level (primary and secondary) with the percentage of $61.2 \%$. All respondents lived with their parents and the majority family-type was nuclear family (63.3\%). The average aged of partner was 20 years old, with the youngest 17 years and the oldest 30 years old. Most of them were still students and only $10 \%$ of them worked. Half of respondents have insufficient knowledge $(53.1 \%)$ primarily they did not understand the anatomy of reproductive organs, such as the ovaries, fallopian tubes in females, and testes, prostate and scrotum in males. 
Table 1. Personal Characteristics.

\begin{tabular}{|c|c|c|c|}
\hline Variables & Variables & f & $\%$ \\
\hline Age & $\begin{array}{l}\geq 17 \text { years } \\
<17 \text { years }\end{array}$ & $\begin{array}{l}22 \\
27\end{array}$ & $\begin{array}{l}44,9 \\
55,1\end{array}$ \\
\hline Last education & $\begin{array}{c}\text { Primary school } \\
\text { Secondary school } \\
\text { Senior high school }\end{array}$ & $\begin{array}{c}5 \\
25 \\
19\end{array}$ & $\begin{array}{l}10,2 \\
51,0 \\
38,8\end{array}$ \\
\hline Occupational history & $\begin{array}{c}\text { Ever worked } \\
\text { Never worked }\end{array}$ & $\begin{array}{l}33 \\
16 \\
\end{array}$ & $\begin{array}{l}67,3 \\
32,7 \\
\end{array}$ \\
\hline Home status & Lived with parents & 49 & 49 \\
\hline Family type & $\begin{array}{c}\text { Single parent } \\
\text { Nuclear family } \\
\text { Extended family }\end{array}$ & $\begin{array}{c}13 \\
31 \\
5\end{array}$ & $\begin{array}{l}26,5 \\
63,3 \\
10,2\end{array}$ \\
\hline $\begin{array}{l}\text { Knowledge level on } \\
\text { reproductional health }\end{array}$ & $\begin{array}{l}\text { Insufficient } \\
\text { Sufficient }\end{array}$ & $\begin{array}{l}26 \\
23\end{array}$ & $\begin{array}{l}53,1 \\
46,9\end{array}$ \\
\hline $\begin{array}{c}\text { Attitude toward premarital } \\
\text { sexual behavior }\end{array}$ & $\begin{array}{c}\text { Permissive } \\
\text { Not permissive }\end{array}$ & $\begin{array}{l}23 \\
26 \\
\end{array}$ & $\begin{array}{l}46,9 \\
53,1\end{array}$ \\
\hline Category of locus of control & $\begin{array}{c}\text { Internal } \\
\text { External } \\
\end{array}$ & $\begin{array}{c}7 \\
42 \\
\end{array}$ & $\begin{array}{l}14,3 \\
85,7 \\
\end{array}$ \\
\hline Religiosity level & $\begin{array}{l}\text { High } \\
\text { Low }\end{array}$ & $\begin{array}{l}28 \\
21\end{array}$ & $\begin{array}{l}57,1 \\
41,9\end{array}$ \\
\hline First age of dating & $\begin{array}{l}10-15 \\
16-21\end{array}$ & $\begin{array}{l}34 \\
15\end{array}$ & $\begin{array}{l}69,4 \\
30,6\end{array}$ \\
\hline Frequency of dating (times) & $\begin{array}{c}1-6 \\
7-12 \\
>13\end{array}$ & $\begin{array}{c}34 \\
8 \\
7\end{array}$ & $\begin{array}{l}69,4 \\
16,3 \\
14,3\end{array}$ \\
\hline Reason for dating & $\begin{array}{c}\text { Trial or curious } \\
\text { ing of love and attracted } \\
\text { Selecting life couple } \\
\text { Considered to be socialized and } \\
\text { able to get lover } \\
\text { Others }\end{array}$ & $\begin{array}{c}6 \\
34 \\
4 \\
2 \\
3\end{array}$ & $\begin{array}{c}12,2 \\
69,4 \\
8,2 \\
4,1 \\
6,1\end{array}$ \\
\hline Place of dating & \begin{tabular}{|c} 
Public places (food court and \\
tourist objects) \\
Homes \\
Internet cafes \\
Quiet places (streets, rice fields) \\
Others (school)
\end{tabular} & $\begin{array}{c}19 \\
26 \\
2 \\
1 \\
1\end{array}$ & $\begin{array}{c}38,8 \\
\\
53,1 \\
4,1 \\
2,0 \\
2,0\end{array}$ \\
\hline $\begin{array}{c}\text { Characteristics of partners } \\
\text { Average age: } 20, \text { min age: } 17, \\
\text { max age: } 30\end{array}$ & $\begin{array}{l}\text { Students } \\
\text { Worker }\end{array}$ & $\begin{array}{c}44 \\
5\end{array}$ & $\begin{array}{l}90 \\
10\end{array}$ \\
\hline
\end{tabular}

\subsection{Knowledge and beliefs about the outcome of first sexual intercourse}

There were beliefs in myths in sexual intercourse. Some respondents assumed that pregnancy can be prevented by jumping immediately after sex and eating sour fruit (such as pineapple, Javanese tamarind, etc.). They believed that pregnancy will not occur when having sex intercourse for the first time and only once. It was as also mentioned by one respondent in an in-depth interview as follows:

"I don't know the process of pregnancy, but I know that sexual intercourse may lead to pregnancy .... I don't understand fertile period..", friends said you should jump after an intercourse in order that there's nothing left inside vagina." (SP1, 19 years old) 
"I do not understand the process of pregnancy.. what is a fertile period? I've ever heard but I don't understand ... "I only know that I will not be pregnant by doing intercourse once only" (SP3, 14 years old)

Most of them have lack of knowledge on sexual and reproductive health, particularly for the younger one, since sexual education has never provided in school and home for young people, digital media such as social media and traditional media as sources to access SRH information as they need.

\subsection{Attitudes towards premarital sexual behaviour}

Nearly half of the respondents' attitude toward premarital sex were more permissive $(47 \%)$ with the locus of control was most heavily influenced by external factors $(85.7 \%)$ such as boyfriends and peers. More than half (57.1\%) admitted to be religious, but they understood religion as a way of life and only rituals. Friend's influence was found to be more powerful to do the risky things that should be avoided. Parental controls were found insufficient in their social life because their parents mostly busy with their own occupation as farmers or factory labours. Most of them were categorized come from family with low socio-economic status.

"as a guidance of life...it means that life needs something to hold...when doing sexual intercourse, I just found that it was not allowed in this occurrence (pregnant)...I did not understand before if it is forbidden in religion..." (SP2, 17 years old)

"of course it was important, but when I was reminded to do a prayer, I sometimes only do wudhu hahaha...or sleeping in front of TV in order not to be disturbed (to be told to do a prayer).." (SP5, 17 years old)

Most of the respondents were first dating at the young ages of 10-15 years (69.4\%) with the number of dating relationships on average of 4-5 times (69.4\%). The reason they started dating at that age $(69.4 \%)$ because of feelings in love, just wanted to try, or wanted to know $(12.2 \%)$.

Table 2. Characteristics of the social environment.

\begin{tabular}{|c|c|c|c|}
\hline Variable & Category & f & $\%$ \\
\hline Pornography access experience & Ever & 31 & 63,3 \\
& Never & 18 & 36,7 \\
\hline Attitude of friends toward & Not permissive & 29 & 59,2 \\
premarital pregnancy & Permissive & 20 & 40,8 \\
\hline Attitude of parents toward & Accepting & 40 & 81,6 \\
premarital pregnancy & Refusing & 9 & 18,4 \\
\hline Attitude of community toward & Accepting & 28 & 57,1 \\
premarital pregnancy & Refusing & 21 & 42,9 \\
\hline
\end{tabular}

Table. 2 shows that the majority of respondents had an easy access to pornography video $(63.3 \%)$. Almost half of them had a friend who is permissive to premarital sex $(41.8 \%)$. It was confirmed by the results of the in-depth interviews saying that most of their friends had experienced of premarital sex after watching a pornographic movie/ video and had a friend who had unwanted pregnancies.

"Well, there is a marriage because of being pregnant first... about 1-2 friends, luckily their boyfriends were responsible...so my friends did not try abortion. When we were watching it (the porn film) only for fun when gathering...later on when one movie has already finished, 
it was deleted and change with the other one.. Once I had in mind to do it (sex) because of the movie, but of course later after I am getting married. "(SP4, 19 years old)

\subsection{Parents' responses to daughter premarital pregnancy}

Most parents of the respondents (81.6\%) were finally accepted against the premarital pregnancy of the respondents, although they were initially angry, disappointed, and shocked over the incident. It was demonstrated by asking for their partner's responsibility to marry their daughter immediately so that the respondents had married status during pregnancy in order to minimize stigma from the society. More than half $(57.1 \%)$ of the surrounding community was resistant against premarital pregnancy, usually by gossiping and flouting the family. After the teenager was married, over time, people could receive them as usual as before. The flurry parents in making a living and the family economy makes them lack of attention to their adolescents. In fact, there were some parents who did not know their daughters' pregnancy as they had just realized when their daughter would give birth in a midwife.

"My father and mother only knew when I gave birth, they and my uncles were angry and cried, I heard...finally I just told on the third or fourth day...that's enough do not repeat again. People told the boy to be responsible, but they are just fine... when we met they are just fine.." (SP6, 17 years old)

"My parents and parents in law just knew on May 5th, they were shocked, but I did not know their reaction. I never socialized with neighbours. When I got married, I looked pregnant..." (SP7, 18 years old)

"I was disappointed, angry but what else... in my thought, my daughter should be married soon ..mm. her boyfriend must be responsible, the most important thing is that my daughter can get married ... cause already pregnant it's okay - the important thing is her boyfriend should responsible for her pregnancy. There are her friends who are pregnant without any husband... it was ashamed her family.." (parent, 50 years)

Table 3. Premarital sexual behaviour.

\begin{tabular}{|c|c|c|c|}
\hline Variable & Category & $\mathrm{f}$ & $\%$ \\
\hline $\begin{array}{l}\text { First age when doing sexual } \\
\text { intercourse }\end{array}$ & $\begin{array}{l}12-15 \\
16-19\end{array}$ & $\begin{array}{c}5 \\
44\end{array}$ & $\begin{array}{l}10,2 \\
89,8\end{array}$ \\
\hline $\begin{array}{l}\text { Reasons for doing sexual } \\
\text { intercourse }\end{array}$ & $\begin{array}{c}\text { Trial or curious } \\
\text { Fulfilling sexual desire } \\
\text { As a proof of love } \\
\text { Forced and persuaded } \\
\text { Celebrating particular days } \\
\text { Others } \\
\end{array}$ & $\begin{array}{c}3 \\
3 \\
24 \\
14 \\
1 \\
4\end{array}$ & $\begin{array}{c}6,1 \\
6,1 \\
49 \\
28,6 \\
2,0 \\
8,2\end{array}$ \\
\hline $\begin{array}{l}\text { Feeling after doing sexual } \\
\text { intercourse }\end{array}$ & $\begin{array}{l}\text { Very sorry and worried } \\
\text { A little sorry and a little worry } \\
\text { No regret and no worry }\end{array}$ & $\begin{array}{c}31 \\
14 \\
4 \\
\end{array}$ & $\begin{array}{c}63,3 \\
28,6 \\
8,2 \\
\end{array}$ \\
\hline
\end{tabular}

\subsection{Respondents' responses for the first sexual intercourse}

Table 3 shows that the respondents had sexual intercourse for the first time at the ages of 16$19(89,8 \%)$ with the reason to prove their love (49\%) and forced and courted (28.6\%). Most respondents felt regret, afraid, and worried after their first sexual intercourse $(63.3 \%)$.

From in-depth interviews show, some respondents stated that; although they had a regret 
for having sex for the first time, eventually they did it several times because of fear of being left by their boyfriends, threatened to be left behind when it was not being taken, or due to the promise to marry. In average, the sexual intercourse occurred after their courtship for 35 months.

"... the one who raped me was the 19th years person... at that moment I was told to go to his house...I was taken by my friend, then I was forced and threatened to be killed, he had a weapon like a crescend/sickle...I tried to fight but I was too weak...that's it...I was afraid to shout...he said he ever killed people, his neighbours were also afraid..." (SP9, 14 years old).

\subsection{Respondents' responses to their premarital pregnancy}

There were respondents who tried to have an abortion when experiencing their pregnancy, but few of them cancelled as it was expensive and not allowed by their partners as well as they did not have much money. According to the respondents, abortion was one solution that can solve their pregnancy problem without being noticed by the family. They had an abortion by drinking anti pregnant or boiling herbs that were believed to kill the foetus/embryo.

"Stress, confused, wanted to abort, when I had been one month late, I checked...I was often sick and when examined the midwife said that I was in early pregnancy...I was scared to be lied again, don't know what to do, shy, wanted to have an abortion but I had no money. My friend who wanted to do abortion said that it is expensive and don't know where...it is expensive and my boyfriend did not give permission..." (SP2, 18 years old)

"well, firstly, my boyfriend said to do abortion because I'm still a student, especially he was not ready to have a baby...he told me to obey him by doing abortion...I tried to buy sprite after school in a small shop, but when I waited for my menstruation, it didn't come on the routine date...I have ever gone to see a traditional midwife, I took herbs, alcohol, and fermented cassava at the same time...but there's no reaction of my pregnancy and the pregnancy still continue..." (SP3, 18 years old)

After failed to do an abortion and remained pregnant, the respondents were stress and depressed, and they felt hopeless to achieve their ideals and future life. The respondents were not ready to be a mother because she has not worked yet. Then, with support from her family of husband family, they eventually would accept to continue their pregnancy.

"Actually, I am not ready, no job, and still very young...then two months later I got married and as bride my stomach looked bigger...I am still very young, no job, but my husband is responsible for my future life..." (SP2, 18th)

"I feel that's fine that I have no more future, I must be ready to bear them all, my parents were ashamed, I am ready to get married with everything prepared by them although I am not ready...if I had a job I didn't think of abortion...the burden as a student was also a problem..." (SP3, 18 years)

\subsection{Health Provider services to adolescent's premarital pregnancy}

Most adolescent girls who experienced with premarital pregnancy were less likely to visit health services to receive antenatal care at the right time than the pregnant girls within marriage. Social consequences, such as stigma, rejection and violation from parents, partners, peers and community make adolescents fear and late registered their pregnancy to clinic in the first semester.

For adolescent girls experiencing premarital pregnancy while still at school could mean drop out of school, prone to early marriage, being shamed, stigmatized by community members, peers and expulsion from home. Adolescent pregnancy also increased risk of adverse health, face higher risk of eclampsia, higher risk of low birth weight, preterm delivery and severe neonatal condition. 
"They usually start to check her pregnancy at third month of pregnancy, some of them just checked at the third trimester before delivery. Maybe she went to check their pregnancy in other village midwife because she feels ashamed with her pregnancy." (village midwife, 35 years)

"I come to visit them at home as usual. I said, it's ok to check here (at village midwife), don't worry to be stigma. I tried to make them comfortable to speak with me. So she didn't feel depressed ... I myself often was reported about pregnant teenagers by cadres." (village midwife, 40 years)

\section{Discussion}

\subsection{Adolescent characteristics and premarital pregnancy experiences}

The average age of the adolescents with unwanted pregnancy in this study was at the range aged with higher health risks for both mother and baby. The possible health risks for the mother is the prevalence of premature births due to the incomplete growth of waist structure obstructing the birth canal. Besides, the position of the baby is not good, so the impact is on the risks of neonatal, perinatal and maternal mortality. In addition to health risks, the teens who are pregnant at young age are also at psychological risk. They are not ready to be mothers and still enjoy their adolescence which is a period of turbulent time filled with various introductions and adventures of new things including the experience of interacting with the opposite sex. In the social life, pregnant adolescents are at risk of being stigmatized by their society, to be dismissed from school and could not have opportunity to work because of caring for children. Therefore, they are at risk of limited economic and have no independence life $[18,19]$.

The low educational level of the adolescents with premarital pregnancy will impact closely on economic problems. The research of Kisbiyah shows that the teenagers are difficult to get a job when their education levels are limited and low or busy taking care of children. The situation is exacerbated by the condition of the husband who is generally still at the same age and does not have a job because he still studies and make it difficult to get a job. This leads to prolonged economic difficulties for this new family [19, 20].

All respondents lived in their parents' houses and most of them were in the type of nuclear family. According to Hurlock, family type affects the formation of personality and behaviour of adolescents. Grandparents, or other family members who live together with the family will affect the life pattern of the family member. There is frequently a difference rules applied between by grandparents and other family members with the ones which adopted by parents to their children. It will make children become confused and tend to follow the rules that make them feel freer. It is proven by the data stating that the adolescents who live with extended family have 48,514 times greater opportunities for high-risk behaviours than those who live with a nuclear family. Meanwhile, according to other previous study shows that not only the type of family influences to adolescent's behaviour, but also influenced by the characteristic of the teenagers themselves who are defiant. The teenagers who have not good communication with their parents tend to make misbehave including to involve in premarital sexual behaviour [21-24].

As stated in previous studies, the adolescent's level of knowledge on sexuality and reproductive health is commonly much lower because sexual and reproductive health educations are not provided in schools. Many parental have no ability to discuss sensitive matter with their children. Therefore, a lot of teens do not understand the traits of puberty and safe sexual intercourse. They think that pregnancy can be prevented by jumping immediately after sex, and pregnancy will not occur during sexual intercourse if only done 
once or for the first time [25]. Besides, lack of information provided by schools and parents, the cultural factor also prohibits talking and discuss about sexuality in public because considered a taboo topic. Hence, adolescents seek their own sources of information from the internet or social media which only teaches how to have sex for fun without informing the impact / consequences of making sexual intercourse [26, 27]. Meanwhile, reproductive health education in schools focuses on the biological aspects only, while the matter of sexuality, gender relations, and rights aspects of adolescents are rated taboo and not important to be given to adolescents [28, 29].

The majority of teens have an external locus of control that associated with the peers influence and partner. Someone who has an external locus of control usually very easily influenced by social environment, lack of confidence, low self-esteem helplessness, and tend to be emotional in dealing with problems.[30] The external factors are more dominant, and they could not control and do not have special skills to prevent or difficult saying no to friends/partners. The friend's environment which is permissive to premarital sex encourages teens to have permissive attitudes toward premarital sexual behaviour. With a low religiosity and the limited understanding of teens in religion, religiosity is not used as the guidelines for making relationship or courtship. Low parental attention and skills to communicate about the issues faced by teens and high influence from surrounding social environment, primarily friends, make teenagers in risky sexual behaviour, and it makes many teens just refer to peers behaviour or role model exemplified through internet [31].

Teenagers who start dating in a very young age tend to be more permissive and more braved to challenge risks associated with sexual intercourse [30, 32]. Most adolescents in this study, in average, changed their boyfriends/ partner around 2-6 times. In fact, there was one respondent who ever changed boyfriends until 23 times. They had a very young age in having relationship between 10-15 years. The previous studies have shown that the age of starting a relationship influences teenager's permissiveness to have sex, even to perform school child prostitution called campus/school chicken or prostitution among university and school students [33]. The younger the teenagers dare to start dating, the more permissive to have multi partner sex [34]. Many reasons are said by teenagers who started dating at a young age, such as: to follow friends, feelings of love, and trial or curious after watching pornography. The experiences of adolescent's courtship were followed with premarital sexual activities, such as hugging, kissing, and up to premarital sex. Enjoyable sexual experience during courtship will lead teens to consider that it is as a normal behaviour. Many of them want to be perceived as a brave teenager. Some opinions mention that sexual behaviour is considered as a maturity status or symbol and as a part of adult people so that the adolescents feel to have the right to do that [31].

\subsection{Adolescent's environmental characteristics}

The advance technology which are expected to provide convenience in communication about good things, has more function at the moment, such as to easier access to pornographic media $[35,36]$. As the previous studies, teens today have almost entirely been accessing to pornography content through the medium of mobile phone. According to Santrock, adolescents exposed to pornographic media continuously have increased sexual desire in them. It makes teens do not think long to imitate what they see. Teens consider their expertise and sexual satisfaction are just like the ones exhibited by the pornographic media they see [37].

More than half adolescents had permissive attitude toward sexuality because their friends agreed that sexual intercourse may be performed by those who are dating. Many adolescent's friends believed; if they do not have sexual intercourse in a relationship, it means that she is not "sold" or nobody want to marry them. Nearly half of the respondents' friends had a 
permissive attitude toward premarital sexual behaviour. Peers have a very dominant contribution from the aspect of the influence and demonstration or modelling in adolescents' sexual behaviour. It is supported also by Hurlock that teens in daily social life tend to be clustered and feel safe in the group. They will feel accepted by the group when having similar behaviour no matter the behaviour corresponds to the norms or deviant without thinking of the consequences will happen to her and family [38, 39].

The attitude of parents determined the response of adolescent pregnancy. The results are consistent with the research conducted by Kisbiyah that many parents are disappointed and angry when they heard about their teenager's pregnancy. However, at the end, they can receive the pregnancy and prevent to do abortion because of fear of $\sin$. Then, it is better to marry their daughter soon. Marriage is the solution which is most often performed by parents when the face of premarital pregnancy problem in adolescents. It is considered to cover the family disgrace. The impact on the teenagers were: dropout from school, having difficulty to reach the ambitions, less attention of parents. In other hand, based on the results of the indepth interviews, it was noted that some respondents had tried to have an abortion by taking drugs accelerating menstruation, soda, alcohol and going to the midwives with the help of her partner. It was conducted by the respondents due to embarrassment and fear of the parental knowing. In addition, they were not ready and did not understand how to deal with unwanted pregnancies [40].

The pregnancy out of marriage in Indonesian cultural and social norms is considered as evil and labelled as immoral [22]. The results of the in-depth interviews show that covering the pregnancy was the first thing to do when the respondents found out their pregnancy. The respondents did not know for certain people's judgment of her because the respondents spent more time at home. It shows that the respondents had fear and shame to interact with the community. The social sanction given by the people was limited to spreading rumors at the beginning and did not last longer when a marriage was immediately held.

\subsection{Adolescent's responses to premarital pregnancy experiences}

Most respondents had sex for the first time at the age of 12-19 years (75.5\%). Sexual intercourse committed by the teenagers at young age occurred because of the social control which was too tight or too loose from parents or society, the frequency of meetings with girlfriends/ boyfriends, family situations which are not in harmony, economic status, peer pressure, loss of moral control, and the manifestation of love with girlfriends/ boyfriend [41]. The majority of the respondents felt very sorry for the shame of unwanted pregnancies.

The respondents were afraid that their spouses would not take the responsibility, being scolded by parents, and being expelled from school. It is in line with the research of Kisbiyah finding out very severe psychological problems faced by teenagers when dealing with the consequences of negative behaviour. Worry, stress, and even depression begin to develop in teenagers when they are pregnant. They are anxious because they have come out of an ideal view of adolescents dealt by families and communities [19].

\subsection{Limitation and strength of this study}

This study focuses on the exploration and description of adolescent personal characteristics, experiences and socio-environmental responses on premaritalpregnancy in Demak Regency with relatively geographically more rural/suburban area. Therefore, perhaps it would be difference with adolescents' characteristics and experiences who live in urban or metropolitan area. The findings of this study could be applied in other regencies in Central Java which have similar socio-economic and socio-cultural setting. 


\section{Conclusion and recommendation}

The prevalence of premarital pregnancy in this study was in an average age of 17 years with the most educational background of junior high school graduates and lived in rural areas with low family's socioeconomic levels. The busyness of parents to earn a living made the teenagers get less attention and easy to be influenced by the risky behaviour due to peer's force. Having a low level of knowledge about reproductive health, permissive attitudes toward risky sexual behaviour, coercion of partners, and easy access to sexual pornography made the teenagers commit sexual intercourse with the risk of premarital pregnancy. Parents' decision-making by immediately marrying them to cover family disgrace was in response to reducing the stigma of society. Teens who were not ready for pregnancy were shown in the four respondents who tried to have an abortion.

It is necessary to provide comprehensive education on sexual and reproductive health and the consequences of premarital sex to both male and female adolescents based on the characters of the adolescents (adolescent friendly services) before they enter a period of having relationship at schools. Life skill education needs to be included in school activities in order to prevent adolescents from engaging in risky and irresponsible behaviours. Parents' skill in communicating and paying attention to their teenagers should be improved since teenagers are curious and trying to find their self-identity which may cause problems to be solved by their families.

\section{References}

1. Badan Pusat Statistik, Sensus Penduduk 2010 - Indonesia, Jakarta (2010)

2. Badan Koordinasi Keluarga Berencana Nasional, Kajian Profil Penduduk Remaja (1024 Tahun), Jakarta (2011)

3. C. T. Halpern et al., Perceived Physical Maturity, Age of Romantic Partner, and Adolescent Risk Behavior, Prev Sci, vol. 8, pp. 1-10 (2007)

4. N. A. Jama, A. Wilford, L. Haskins, A. Coutsoudis, L. Spies, and C. Horwood, Autonomy and infant feeding decision-making among teenage mothers in a rural and urban setting in KwaZulu-Natal, South Africa, BMC Pregnancy Childbirth, vol. 18, no. 1 , p. 52 (2018)

5. R. Rundle, H. Soltani, and A. Duxbury, Exploring the views of young women and their healthcare professionals on dietary habits and supplementation practices in adolescent pregnancy: a qualitative study, BMC Nutr., vol. 4, no. 1, p. 45 (2018)

6. H. Soltani, A. Duxbury, R. Rundle, and K. Marvin-Dowle, Dietary habits and supplementation practices of young women during pregnancy: an online crosssectional survey of young mothers and health care professionals, BMC Nutr., vol. 3, no. 1 , p. 19 (2017)

7. S. Stagi, L. Cavalli, C. Iurato, S. Seminara, M. L. Brandi, and M. De Martino, Bone metabolism in children and adolescents: main characteristics of the determinants of peak bone mass (2013)

8. S. Kar, A. Choudhury, and A. Singh, Understanding normal development of adolescent sexuality: A bumpy ride, J. Hum. Reprod. Sci., vol. 8, no. 2, p. 70 (2015)

9. D. L. Badriah, Gizi dalam Kesehatan Reproduksi. Bandung: Refika Aditama, (2011)

10. Kemenkes RI, Infodatin Reproduksi Remaja, Jakarta (2017)

11. Badan Kependudukan dan Keluarga Berencana Nasional, Survei Demografi dan Kesehatan Indonesia 2017: Buku Remaja. Jakarta (2018)

12. A. Saksono, Tingginya Kehamilan Remaja Tuntut PKBI Jateng Susun Program Kerja 2015-2018. [Online]. Available: https://pkbijateng.or.id/tingginya-kehamilan-remajatuntut-pkbi-jateng-susun-program-kerja-2015- 2018/. Accessed: 24 Sep (2019) 
13. D. Ocviyanti and M. Dorothea, Aborsi di Indonesia, J. Indones. Med. Assoc., vol. 68, no. 6, pp. 213-215 (2018)

14. Z. D. Fahmi, Revitalisasi Fungsi dan Eksistensi Islam dalam Prostitusi Pantura, University of Indonesia, Jakarta (2010)

15. Dinas Kesehatan Kabupaten Demak, Laporan Persalinan Remaja di Bawah Usia 20 Tahun 2014, Demak (2014)

16. H. Nassaji, Qualitative and descriptive research: Data type versus data analysis, Lang. Teach. Res., vol. 19, no. 2, pp. 129-132 (2015)

17. H. Kim, J. S. Sefcik, C. Bradway, and G. Nursing, Characteristics of Qualitative Descriptive Studies: A Systematic Review HHS Public Access, Res Nurs Heal., vol. 40, no. 1, pp. 23-42 (2017)

18. J. Osok, P. Kigamwa, K.-Y. Huang, N. Grote, and M. Kumar, Adversities and mental health needs of pregnant adolescents in Kenya: identifying interpersonal, practical, and cultural barriers to care, BMC Womens. Health, vol. 18, no. 1 (2018)

19. Y. Kisbiyah, Konsekuensi psikologis dan sosial-ekonomi kehamilan tak dikehendaki pada Remaja, Populasi, vol. 5, no. 2 (2006)

20. B. Kemi, O. Christian, J. A. Alabi, and O. Isola, Unplanned Parenthood: The SocioEconomic Consequences of Adolescent Child-bearing in Nigeria, J. Educ. Pract., vol. 6, no. 31, pp. 15-18 (2015)

21. S. P. E. Dávila, J. Champion, M. G. Monsiváis, M. Tovar, and M. L. F. Arias, Mexican Adolescents' Self-Reports of Parental Monitoring and Sexual Communication for Prevention of Sexual Risk Behavior, J. Pediatr. Nurs., vol. 35, pp. 83-89 (2017)

22. M. Ali and M. Asrori, Psikologi remaja: perkembangan peserta didik. Bandung: Bumi Aksara (2010)

23. K. M. Sisco, S. L. Martins, E. K. Kavanagh, and M. L. Gilliam, Parent-Daughter Communication About Abortion Among Nonpregnant African-American Adolescent Females, J. Adolesc. Heal., vol. 55, pp. 835-841 (2014)

24. S. Bastien, L. J. Kajula, and W. W. Muhwezi, A review of studies of parent-child communication about sexuality and HIV/AIDS in sub-Saharan Africa, Reprod. Health, vol. 8, no. 1, p. 25 (2011)

25. R. Ariyani, Kesehatan remaja: problem dan solusinya. Jakarta: Salemba Medika, (2010)

26. M. Azinar, Perilaku Seksual Pranikah Beresiko terhadap Kehamilan Tidak Diinginkan, J. Kesehat. Masy., vol. 8, no. 2, pp. 137-145 (2013)

27. R. K. Jones and A. E. Biddlecom, Is the Internet Filling the Sexual Health Information Gap for Teens? An Exploratory Study, J. Health Commun., vol. 16, no. 2, pp. 112-123 (2011)

28. D. T. Pakasi et al., Antara Kebutuhan dan Tabu: Pendidikan Seksualitas dan Kesehatan Reproduksi bagi Remaja di SMA, Makara Seri Kesehat., vol. 17, no. 2, pp. 79-87 (2013)

29. A. K.-J. Macintyre, A. Rosa, M. Vega, and M. Sagbakken, From disease to desire, pleasure to the pill: A qualitative study of adolescent learning about sexual health and sexuality in Chile, BMC Public Health, vol. 15, no. 1, p. 945 (2015)

30. A. Gevers, C. Mathews, P. Cupp, M. Russell, and R. Jewkes, Illegal yet developmentally normative: A descriptive analysis of young, urban adolescents' dating and sexual behaviour in Cape Town, South Africa, BMC Int. Health Hum. Rights, vol. 13, no. 1 (2013)

31. E. A. Borawski, C. E. Ievers-Landis, L. D. Lovegreen, and E. S. Trapl, Parental Monitoring, Negotiated Unsupervised Time, and Parental Trust: The Role of Perceived Parenting Practices in Adolescent Health Risk Behaviors, J Adolesc Heal., 
vol. 33, no. 2, pp. 60-70 (2003)

32. N. Meilani, Z. Shaluhiyah, and A. Suryoputro, Perilaku Ibu Dalam Memberikan Pendidikan Seksual Pada Remaja Awal, J. Kesehat. Masy. Nasional, vol. 8, no. 8, pp. 411-417 (2014)

33. D. A. Widyastari, P. Isarabhakdi, and Z. Shaluhiyah, Women Won't Get Pregnant with one Sexual Intercourse Misconceptions in Reproductive Health Knowledge among Indonesian Young Men, J. Heal. Res., vol. 29, no. 1, pp. 63-69 (2015)

34. Z. Shaluhiyah, A. Suryoputro, and A. Setyawati, The Needs of Information Services on Reproductive Health, STIs, and HIV in Middle Adolesce, J. Kesehat. Masy., vol. 12, no. 2, pp. 233-242 (2017)

35. S. Notoatmodjo, Promosi Kesehatan dan Perilaku Kesehatan. Jakarta: Rineka Cipta (2014)

36. K. Walker and E. Sleath, A systematic review of the current knowledge regarding revenge pornography and non-consensual sharing of sexually explicit media, Aggress. Violent Behav., vol. 36, pp. 9-24 (2017)

37. J. W. Santrock, Perkembangan Masa Hidup, 13 Jilid 1. Jakarta: Erlangga (2012)

38. B. Peçi, Peer Influence and Adolescent Sexual Behavior Trajectories: Links to Sexual Initation, Eur. J. Multidiscip. Stud., vol. 2, no. 3, pp. 96-105 (2017)

39. L. Widman, S. Choukas-Bradley, S. W. Helms, and M. J. Prinstein, Adolescent Susceptibility to Peer Influence in Sexual Situations, J Adolesc Heal., vol. 58, no. 3, pp. 323-329 (2016)

40. C. Shu et al., Association between age at first sexual intercourse and knowledge, attitudes and practices regarding reproductive health and unplanned pregnancy: a cross-sectional study, Public Health, vol. 135, pp. 104-113 (2016)

41. E. Eggleston, Unintended pregnancy and women's use of prenatal care in Ecuador, Soc. Sci. Med., vol. 51, pp. 1011-1018 (2000) 